Research Article

\title{
Educational Technology Research Trends in Turkey: Investigating Graduate Theses in English Language Teaching
}

\author{
Osman SOLMAZ *1 (D) \\ ${ }^{1}$ Dicle University, Turkey, osolmaz@dicle.edu.tr \\ *Corresponding Author: osolmaz@dicle.edu.tr
}

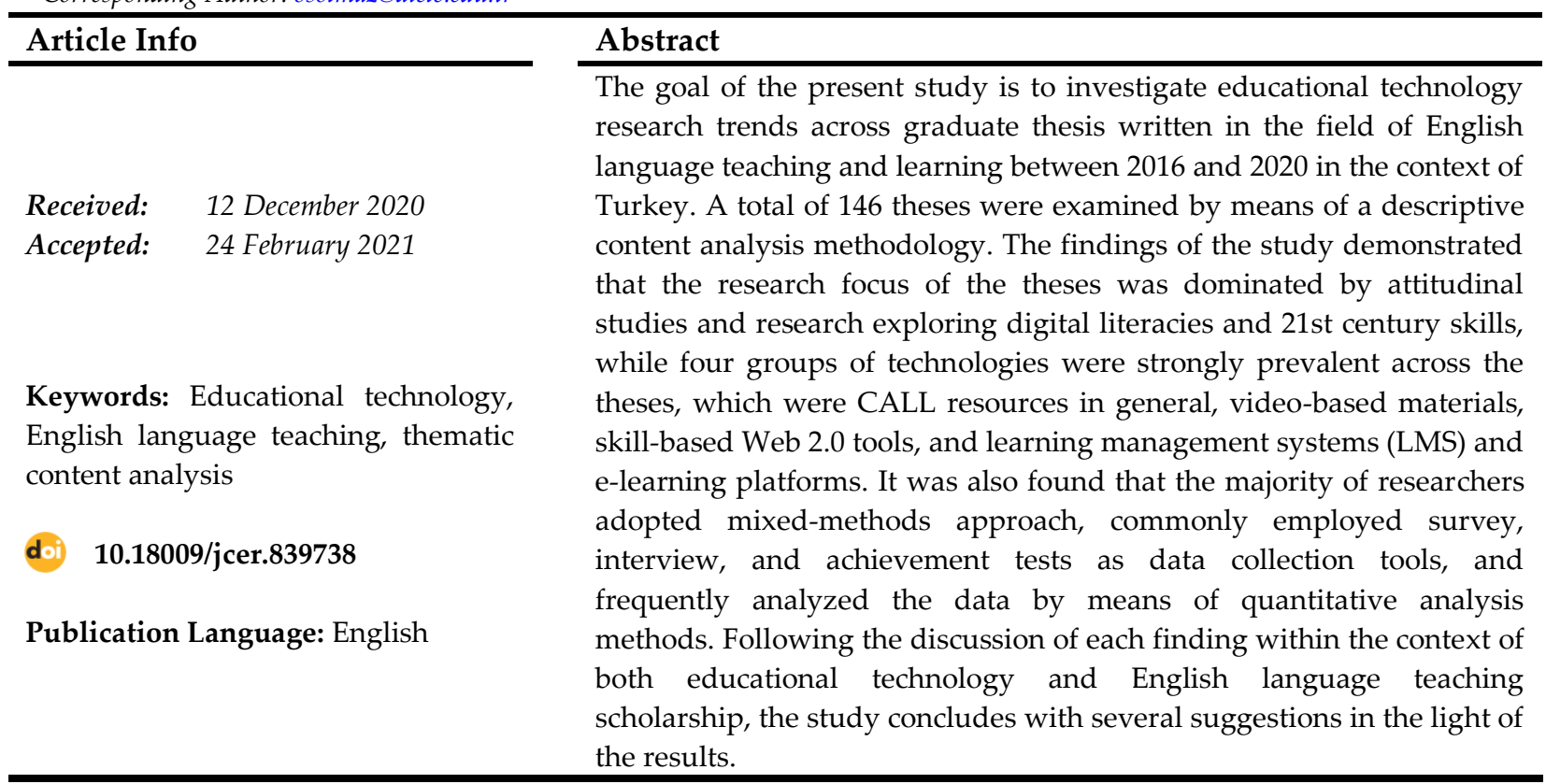

open access (

To cite this article: Solmaz, O. (2021). Educational technology research trends in Turkey: Investigating graduate theses in English language teaching. Journal of Computer and Education Research, 9 (17), 102-124. DOI: 10.18009 /jcer.839738

\section{Introduction}

The rapid development of information and communication technologies has created new avenues for education including language teaching and learning contexts. The ubiquity of internet technologies, particularly mobile devices with internet service, provided opportunities for learners to engage in a multitude of literacy practices without spatiotemporal limitations (Kessler, 2018). These changes sparked a growing interest in educational technology research, which systematically addressed the integration and impact of technologies into educational contexts across the world (Yıldiz, Cengel, \& Alkan, 2020). The high number of research exploring educational technologies facilitated an increase in review studies, in which different aspects of such technologies were analyzed (e.g., Chen, 
Chen, Jia, \& An, 2020; Strelan, Osborn, \& Palmer, 2020). Such a comprehensive analysis of research in a particular topic can provide a deeper and clearer understanding of the phenomena investigated (Dirlikli, Aydın, \& Akgün, 2016). A similar strand of research exploring the role of digital technologies has also emerged in the contexts of second language teaching and learning (e.g., Parmaxi \& Zaphiris, 2016; Shadiev, Hwang, \& Huang, 2017). However, there remains a dearth of research analyzing educational technology research trends in certain fields including English language teaching. Therefore, it is the intention of the present study to address this discrepancy through investigating the research trends across graduate theses with a focus on educational technologies, which are published between 2016 and 2020 in the field of English language teaching in the context of Turkey.

Digital competence training, pre-service teachers have improved in using information searching strategies, accessing information, evaluating the validity and reliability of information, organizing and storing information (Çebi \& Reisoğlu, 2019). Digital competence trainings improved preservice teachers' skills of searching for information on the web (Ramírez-Montoya, Mena, \& Rodríguez-Arroyo, 2017). The purpose of this study is to find out if there is any gap of teachers between their Online Education skills. We are residing in a planet where technology is contemporary in our life routines. Online Learning is one of the vastest revolutions in individuals' lifespans. They give mobility and excitement to its users that these modern technological devices become most significant part of many people's lives. From online banking to watch the news on TV, we are confronting the progressions and affects that convey to our lives. Schools couldn't stay out of these online progressions and a wide range of classrooms had been altered, giving its place to virtual classrooms, from special spaces for the perusing of scholarly messages being delivered via social media platforms to sight and sound spaces, where the utilization of data and correspondence innovation had accomplished incredible significance in Online learning.

\section{Literature Review}

The present section lays out a brief review of the literature exploring educational technology trends in English language teaching and learning spaces within the context of Turkey. Considering the limited number of research in this particular area, the trends across the previous research in Turkish context are covered from two main perspectives: the 
research trends in the field of educational technology, and the syntheses centered on the trends in English language teaching.

Prior studies were synthesized in terms of both educational technology in general (e.g., Yildiz et al., 2020) and the use of educational technology particularly for language teaching and learning purposes (e.g., Parmaxi \& Zaphiris, 2016) in a worldwide setting. A similar trend was followed for the scholarship in educational technology (e.g., Gökmen et al., 2017) and English language teaching in the context of Turkey (e.g., Özmen, Cephe, \& Kınık, 2016). While some of the research explored the trends across the scholarship by mainly analyzing graduate theses (e.g., Uzunboylu \& Kocakoyun, 2016), others synthesized research published in internationally indexed journals as well (Solak, 2014). It is also important to note that a majority of the scholarship conducting research synthesis was published in 2016 or later, which illustrate a recent picture of the trends in the scholarship.

Content analyses of the educational technology study trends in Turkey were performed in multiple studies including an early research by Göktaş et al. (2012), who investigated Turkish educational technology research published between the years of 20002009. The analysis revealed that educational environments and technology were frequently at the center of the research, while questionnaires and quantitative analyses were employed as data collection tools and quantitative analysis method, respectively. Similarly, an extensive content analysis, which focused on the articles published by Turkish authors between 1990 and 2011 in the field of educational technology (Küçük, Aydemir, Yildirim, Arpacik, \& Goktas, 2013), showed that educational environments and technology, multimedia, and distance education were the most commonly studied subjects. Interviews and questionnaires were frequently adopted as data gathering tools, while sample participants often featured preservice teachers and other undergraduate students. Analyzing doctoral research in educational technology in the Turkish context, Durak, Çankaya, Yunkul, and Misırlı (2018) found that interview, questionnaires, and scales were frequently used for data gathering purposes, and the participants often included university students. Unlike the previous research, mixed method was the most commonly used method in dissertations in educational technology. Another area of research concentrated on particular aspects of educational technology research such as distance education in Turkey. For example, Gökmen 
et al. (2017) analyzed research trends on distance education graduate research produced between 2005 and 2014, Durak et al. (2017) examined master's theses on distance education in higher education context between 1986 and 2015. Both studies showed that quantitative methodology was the most frequently adopted research design, while survey/questionnaire was the most commonly used method to collect data. In addition, both descriptive and inferential analyses were adopted for data analysis, which commonly gathered from undergraduate students and adults.

Given the focus of the present study on educational technology theses in English language teaching and learning, it is worthwhile examining research trends across the articles and theses published in the relevant field of study in the context of Turkey. Being one of the studies investigating the research trends across papers published between 2009 and 2013, Solak's (2014) synthesis revealed that quantitative method was employed the most, while the commonly preferred sample group was undergraduate students and 31-100 sample size was the most common group. In another study, Yağız, Aydın, and Akdemir (2016) reviewed research articles published in journals between 2005 and 2015, and found similar results in terms of research design, data collection tool, sample group and sample size. They have also noted that language acquisition/learning, language teaching, and teacher education were themes which were commonly investigated. In another research exploring the abstracts of English Language Teaching (ELT) research in a Turkish journal database platform, Cesur, Kök, and Aydın, (2018) found that teacher education, curriculum and teaching materials, and language teaching were frequently examined by researchers, undergraduates were the most common participant group, and sample size was 31-100 in the majority of the research. Finally, in their comprehensive review of Turkey-based ELT research, Aydınlı and Ortaçtepe (2016) showed that main topics of investigation were centralized around language learning and learners, English language teaching and language teachers, and in-service and pre-service teacher education/professional development.

The other research strand consisted of studies performing content analysis of master's and doctoral theses published in ELT scholarship in Turkey. In an early study, Kırmızı (2012) found language skills, teaching method, psychology and language teaching as the widely researched areas of study across master's theses. Examining doctoral research between 2009 
and 2013 in ELT, İnal, Özdemir, Kıray, and Oral (2016) reported that classroom teaching and learning was at the center of attention in the majority of research, while theses often featured quantitative research methodologies and adult learners as sample groups. Exploring doctoral research in the same context, Özmen et al. (2016) found that multiple aspects of Teaching English as a foreign language (e.g., teaching language skills, certain variables such as learner and teacher) were among the commonly examined areas, while dissertations investigating young learners were reported to be quite limited. Finally, Şişman, Büyükkarcı and Özyurt (2019) documented the broad picture of the research trends across ELT graduate theses and reported that a) vocabulary and assessment were the most common choices as the topic of investigation, b) sample size in the research was often 31-60, and c) mixed method was the most preferred method. Several studies have also synthesized graduate thesis research by focusing on a particular aspect such as coursebooks and preparatory schools. To illustrate, Şimşek and Dündar (2017) undertook an analysis of research trends in English as a Foreign Language (EFL) coursebook evaluation across graduate theses, and Koçyiğit and Erdem (2018) examined graduate research on English preparatory classrooms at Turkish higher educational settings.

Despite a growing body of content analysis research in the fields of educational technology and English language teaching, the research has yet to document educational technology research trends in ELT contexts in Turkey. In an effort to address the gap in the previous scholarship, the present study aims to analyze ELT graduate theses featuring educational technologies for the period between 2016 and 2020 through the formulated research questions below:

1. What is the distribution of exterior characteristics of the educational technology research in ELT contexts? (type of thesis, year and place of publication)

2. Which topics were commonly investigated in educational technology research in ELT contexts?

3. What kinds of technologies were featured in educational technology research in ELT contexts?

4. Which methods were commonly adopted in educational technology research in ELT contexts? 
5. What are the common data collection tools employed in educational technology research in ELT contexts?

6. Which data analysis methods were utilized in educational technology research in ELT contexts?

7. What are the sampling features of the in educational technology research in ELT contexts?

a. Which sample groups were commonly preferred?

b. Which sample size range was frequently selected?

\section{Methodology}

The present study investigated educational technology theses and dissertations written in the area of English language teaching and learning in the context of Turkey from January 2016 through September 2020. The study adopted a descriptive content analysis methodology, which allows researchers to analyze the collected data to classify the content with respect to general tendencies, emerging themes and trends through a descriptive approach (Yıldırım \& Şimşek, 2013). The selected theses were systematically analyzed to demonstrate certain characteristics, and methodological trends of educational technology theses conducted in connection with ELT scholarship in Turkey.

\section{Data Collection}

The present study comprised master's theses and doctoral dissertations in the intersection of educational technologies and English language teaching and learning. As part of the data collection, graduate theses were gathered through the online electronic thesis database of the Turkish Council of Higher Education (TCHE). The following criteria were devised for the present study; a) The thesis had to be published in the field of English language teaching and learning between 2016 and 2020 (by September), b) The focus of the research had to be related to a single or multiple aspects of educational technology within the context of Turkey, c) The thesis had to be publicly accessible through TCHE's thesis database. The selected theses were identified through the online database's advanced search tool, which allowed the researcher to reach the complete list of master's and doctoral theses published in the department of English language teaching. In order to avoid missing a relevant thesis, the advanced search was performed multiple times as there were 
institutional variations in terms of thesis categorizations (i.e., English Language Education Department, English Language Department, English Language Teaching Department, English Language Teaching). Following the identification of approximately 700 theses according to the first criterion, a total of 149 works featuring an educational technology were found to comply with the second criterion. Finally, three theses were excluded as they were not publicly accessible in the online database system. As a result, a total of 146 theses were used.

\section{Data Analysis}

A combination of coding frameworks was utilized for data analysis in the present study. While one of them (Güler \& Taş, 2020) was employed as it was exclusively used for the analysis of theses in pre-school science education research, the other one (Yağız, Aydın, \& Akdemir, 2016) was preferred for the fact that it was adopted for the examination of publications in the field of ELT. Given the focus of the present study on theses, an adapted version of the coding framework used by Güler and Taş (2020) were selected as the chief analysis method (Table 1). The parameters used in the study were based on both exterior (place of completion, year, type), and content (research and technology focus, research design, data collection tools and analysis, participant groups and sample size) features of the examined theses. Each thesis was investigated through the use of the adapted parameters and presented in multiple formats such as frequency and percentage following the process of analysis.

Table 1. The parameters adopted for the analysis of theses in the present study

\begin{tabular}{|c|c|c|}
\hline Theme & Sub-theme & Description \\
\hline \multirow[t]{2}{*}{ Exterior features } & Place of completion & The university where the work was completed \\
\hline & Year and Type & $\begin{array}{l}\text { The year completed and type of thesis } \\
\text { (Master's/Doctoral) }\end{array}$ \\
\hline \multirow[t]{7}{*}{ Content features } & Research focus & Main theme(s) of the study \\
\hline & Technology focus & Educational technology/ies used for the study \\
\hline & Research design & Quantitative, Qualitative, Mixed-methods \\
\hline & Data collection tools & Interview, survey, observation etc. \\
\hline & Data analysis & Descriptive, inferential, qualitative \\
\hline & Participant groups & Teachers, students, parents etc. \\
\hline & Sample size & The number of participants \\
\hline
\end{tabular}




\section{Findings}

This section features the presentation of the findings by means of the tables created following the analysis of master's and doctoral theses examined in the present study. The findings are presented in accordance with the coding framework and shared in two main categories: Exterior characteristics and content features.

Findings Related to Exterior Characteristics of Theses

The findings are presented with respect to exterior characteristics of theses in this section.

Table 2. Distribution of theses by its type and university

\begin{tabular}{|c|c|c|c|c|c|}
\hline Theme & Code & $\begin{array}{l}\text { Master's } \\
\text { thesis }\end{array}$ & $\begin{array}{l}\text { Doctoral } \\
\text { thesis }\end{array}$ & tf & $\%$ \\
\hline \multirow{17}{*}{$\begin{array}{l}\text { University } \\
\text { Name }\end{array}$} & Bahçeşehir University & 26 & 2 & 28 & 19.18 \\
\hline & Çağ University & 17 & 2 & 19 & 13.01 \\
\hline & Çukurova University & 12 & 3 & 15 & 10.27 \\
\hline & Ufuk University; Uludağ University* & 14 & 0 & 14 & 9.59 \\
\hline & Middle East Technical University & 8 & 1 & 9 & 6.16 \\
\hline & $\begin{array}{l}\text { İstanbul University (Cerrahpaşa); } \\
\text { Sabahattin Zaim University* }\end{array}$ & 8 & 0 & 8 & 5.48 \\
\hline & Akdeniz University; Gaziantep & 8 & 0 & 8 & 5.48 \\
\hline & $\begin{array}{l}\text { University; Pamukkale University; } \\
\text { Samsun Ondokuz Mayıs University* }\end{array}$ & & & & \\
\hline & Gazi University & 6 & 1 & 7 & 4.80 \\
\hline & Hacettepe University & 4 & 3 & 7 & 4.80 \\
\hline & $\begin{array}{l}\text { Abant İzzet Baysal University; Burdur } \\
\text { Mehmet Akif Ersoy University; Dicle } \\
\text { University; Kocaeli University; } \\
\text { Maltepe University; Necmettin } \\
\text { Erbakan University; Süleyman } \\
\text { Demirel University* }\end{array}$ & 7 & 0 & 7 & 4.80 \\
\hline & Balıkesir University & 5 & 0 & 5 & 3.42 \\
\hline & Yeditepe University & 3 & 2 & 5 & 3.42 \\
\hline & Çanakkale Onsekiz Mart University & 1 & 3 & 4 & 2.74 \\
\hline & $\begin{array}{c}\text { Anadolu University; Boğaziçi } \\
\text { University }\end{array}$ & 2 & 2 & 4 & 2.74 \\
\hline & Atatürk University & 2 & 1 & 3 & 2.05 \\
\hline & Muğla Sitk1 Koçman University & 3 & 0 & 3 & 2.05 \\
\hline Total & & 126 & 20 & 146 & 100 \\
\hline
\end{tabular}

* Statistics are equally distributed across the universities.

As frequency and percentage of theses indicated in Table 2, the data comprised of 126 master's theses (86.3\%) and 20 doctoral dissertations (13.7\%) conducted across 28 different higher education institutions. A great number of ELT postgraduate theses $(f=62)$ featuring 
educational technologies were conducted at three universities (Bahçeşehir, Çağ, Çukurova) with a combined ratio of $42.46 \%$. A total of 82 theses were published by twenty-two state universities, which corresponds to an average of 3.72 theses per university, while the remaining 64 theses were conducted at six foundation universities, corresponding to an average of 10.66 theses per university. The fact that there are more master's theses is not surprising considering the relative scarcity of ELT doctoral programs compared to master's programs in Turkey. The number of educational technology-related ELT theses being high at certain universities is likely to be associated with the relevant expertise possessed by the faculty in those institutions.

Table 3. Distribution of theses by year

\begin{tabular}{cccccccc}
\hline Theme & Code & \multicolumn{2}{c}{ Master's thesis } & \multicolumn{2}{c}{ Doctoral thesis } & \multicolumn{2}{c}{ Total } \\
\cline { 3 - 8 } & & f & \% & f & \% & f & \% \\
\cline { 2 - 8 } Years & 2016 & 17 & 13.49 & 4 & 20 & 21 & 14.38 \\
& 2017 & 27 & 21.43 & 1 & 5 & 28 & 19.18 \\
& 2018 & 14 & 11.11 & 9 & 45 & 23 & 15.75 \\
& 2019 & 46 & 36.51 & 4 & 20 & 50 & 34.25 \\
Total & 2020 & 22 & 17.46 & 2 & 10 & 24 & 16.44 \\
\hline
\end{tabular}

Table 3, which displays the distribution of the examined theses by year, showed that the highest number of theses $(f=50)$ were completed in 2019. The overwhelming majority of the research conducted consisted of master's theses $(f=46)$, while the highest number of doctoral dissertations $(\mathrm{f}=9$ ) was achieved in 2018. As seen in the table below, the frequency of the total number of theses indicated that the number of research investigating educational technologies followed a relatively upward trend, which featured a major increase in master's theses in 2019. Given the fact that the last quarter of 2020 was not covered in the present study and the potential delays in graduate research due to COVID-19 outbreak in Turkish higher education context, it can be argued that the research exploring the technological phenomena in English language teaching and learning settings might follow a similar or potentially an upward trend more vertically when the epidemic outbreak is successfully under control.

\section{Findings Related to Content Features of Theses}

The findings with respect to content characteristics of the examined theses are presented in this section. The findings stem from the analysis of content-related areas such as 
research and technology focus of the theses, research design, data collection tools, data analysis, participant groups, and sample size.

Table 4. Distribution of theses by research focus

\begin{tabular}{cccccccc}
\hline Theme & Code & \multicolumn{2}{c}{$\begin{array}{c}\text { Master's } \\
\text { thesis }\end{array}$} & \multicolumn{2}{c}{$\begin{array}{c}\text { Doctoral } \\
\text { thesis }\end{array}$} & \multicolumn{2}{c}{ Total } \\
& & $\mathbf{f}$ & $\mathbf{\%}$ & $\mathbf{f}$ & $\mathbf{\%}$ & $\mathbf{f}$ & $\mathbf{\%}$ \\
\hline & & 56 & 39.16 & 3 & 9.68 & 59 & 33.91 \\
& Digital Literacies \& 21st Century Skills & 14 & 9.79 & 6 & 19.35 & 20 & 11.49 \\
& Flipped Instruction Model & 14 & 9.79 & 3 & 9.68 & 17 & 9.77 \\
Research & Language Development and Use & 15 & 10.49 & 1 & 3.23 & 16 & 9.2 \\
focus & Gamification \& Augmented Reality & 10 & 6.99 & 1 & 3.23 & 11 & 6.32 \\
& Learner Autonomy & 7 & 4.9 & 4 & 12.9 & 11 & 6.32 \\
& Motivation & 6 & 4.2 & 3 & 9.68 & 9 & 5.17 \\
& Dre- and In-service Teacher Education & 4 & 3.5 & 4 & 12.9 & 9 & 5.17 \\
& Other & 12 & 8.38 & 4 & 12.9 & 8 & 4.6 \\
Total & & $\mathbf{1 4 3}$ & $\mathbf{1 0 0}$ & $\mathbf{3 1}$ & $\mathbf{1 0 0}$ & $\mathbf{1 7 4}$ & $\mathbf{1 0 0}$ \\
\hline
\end{tabular}

According to Table 4, the research focus of the theses was varied although attitudinal studies and theses exploring digital literacies and $21^{\text {st }}$ century skills nearly equaled half of the examined theses. Attitudinal research was particularly prevalent across master's theses $(\mathrm{f}=56)$ and it consisted of research exploring the perceptions, attitudes, beliefs, or opinions of various sample groups towards technological tools or technology-enhanced methodologies. Digital literacies, on the other hand, was the most popular research area for doctoral theses $(19,35 \%, f=6)$. The research in this group, which was categorized under the umbrella terms of digital literacies and $21^{\text {st }}$ century skills, was comprised of studies investigating areas such as critical thinking, pragmatic and intercultural communication competences. It is noteworthy that the number of research focusing specifically on language development and use was relatively limited $(9,2 \%, f=16)$ despite being ranked as $4^{\text {th }}$ in the list. Apart from the listed research focus areas such as flipped instruction model, learner autonomy, and motivation, the underexplored research topics, which were listed in the category of 'Other', included anxiety, concept mapping, English for specific/academic purposes, and future labs. These findings correspond well to the previous research with respect to the topics such as language learners and language teachers (e.g., İnal et al., 2016; Özmen et al., 2016), but they are in contradiction with the literature with respect to pre- and in-service teacher education (e.g., Aydınlı \& Ortaçtepe, 2016; Cesur et al., 2018; Yağız et al., 2016). Considering these 
results, it might be argued that educational technology research concerning pre- and inservice EFL teacher education is relatively limited in comparison with the number of teacher education research in the field of ELT in general. The findings regarding the research focus of the studies are also generally in line with the predominantly examined areas in educational technology research, which are reported as educational technology and environment and multimedia (e.g., Göktaş et al., 2012; Küçük et al., 2013). However, the number of research focusing on distance education is low compared to the research trends across the educational technology scholarship (e.g., Küçük et al., 2013).

Table 5. Distribution of theses by technology focus

\begin{tabular}{|c|c|c|c|c|c|c|c|}
\hline \multirow[t]{2}{*}{ Theme } & \multirow[t]{2}{*}{ Code } & \multicolumn{2}{|c|}{$\begin{array}{c}\text { Master's } \\
\text { thesis }\end{array}$} & \multicolumn{2}{|c|}{$\begin{array}{c}\text { Doctoral } \\
\text { thesis }\end{array}$} & \multicolumn{2}{|c|}{ Total } \\
\hline & & $\mathbf{f}$ & $\%$ & $\mathbf{f}$ & $\%$ & $\mathbf{f}$ & $\%$ \\
\hline \multirow{10}{*}{$\begin{array}{c}\text { Technology } \\
\text { Focus }\end{array}$} & CALL resources (general) & 34 & 22.82 & 5 & 22.73 & 39 & 22.81 \\
\hline & Video-based materials & 31 & 20.81 & 4 & 18.18 & 35 & 20.47 \\
\hline & Skill-based Web 2.0 tools & 29 & 19.46 & 4 & 18.18 & 33 & 19.30 \\
\hline & LMS \& E-learning platforms & 13 & 8.72 & 6 & 27.27 & 19 & 11.11 \\
\hline & Social networking sites & 8 & 5.37 & 0 & 0.00 & 8 & 4.68 \\
\hline & Games \& Gamifying tools & 7 & 4.69 & 0 & 0.00 & 7 & 4.09 \\
\hline & Blogs & 5 & 3.36 & 1 & 4.55 & 6 & 3.51 \\
\hline & Virtual/Augmented reality tools & 5 & 3.36 & 0 & 0.00 & 5 & 2.92 \\
\hline & IWBs / Tablets & 5 & 3.36 & 0 & 0.00 & 5 & 2.92 \\
\hline & Others & 12 & 8.05 & 2 & 9.09 & 14 & 8.19 \\
\hline Total & & 149 & 100 & 22 & 100 & 171 & 100 \\
\hline
\end{tabular}

Table 5, illustrating the distribution of the examined theses by technology focus, indicating that four groups of technologies were strongly prevalent across both master's and dissertation research: CALL resources in general, video-based materials, skill-based Web 2.0 tools, and learning management systems (LMS) and e-learning platforms. While the first group often included attitudinal research exploring participants' perceptions towards CALL or MALL resources (e.g., internet technologies, mobile applications) in general $(f=39)$, the second group (i.e., video-based materials) consisted of technologies such as multiple TV series and commercials, animations, TED-Ed videos, video editing tools (e.g., WE-Video, Screencastomatic), and digital storytelling platforms such as Animaker $(20,47 \%, \mathrm{f}=35)$. Skillbased Web 2.0 tools, which specifically developed for improving a particular skill, were also frequently employed in the theses. Some of the examples included tools adopted for developing listening (e.g., audiobooks, Randall's cyber listening lab), writing (e.g., CYWrite, 
Google Docs), reading (e.g., annotation tools, e-readers), and vocabulary (e.g., Rememba, Memrise) ( $\mathrm{f}=33)$. Finally, LMSs and e-learning platforms were commonly utilized in master's theses $(8,72 \%)$ and particularly in dissertation research (27.27\%). Such technologies consisted of mainstream LMSs (e.g., Edmodo, Moodle, AdobeConnect), systems that are developed to address the needs of a particular institution (e.g., Dicle University online LMS, Istanbul University AUZEF online platform), and systems that are designed specifically for language learning purposes (e.g., Cambridge Unlock, MyEnglishLab). In addition to these four categories, social networking sites (e.g., Facebook, Twitter), games and gamifying tools (e.g., MMOGs, Kahoot), blogs (e.g., Wordpress, Blogger), virtual and augmented reality tools (e.g., virtual/augmented reality apps such as HP Reveal 2, Layar, VR Grocery), interactive whiteboards and tablets, and others including corpora (e.g., $B N C, C O C A$ ), and assessment tools (e.g., Google forms, Socrative). Although there is no similar study to make a direct comparison with these findings, it can be argued that these findings are not surprising as multimedia technologies are found to be commonly featured in educational technology research (e.g., Küçük et al., 2013). The finding regarding skill-based Web 2.0 tools also concurs well with the previous studies as language skills are frequently examined across ELT graduate thesis research (e.g., Şişman et al., 2019). What is perhaps surprising is that the investigation of socio-interactive web technologies such as social media and gamifying/augmented reality tools are almost non-existent across doctoral thesis research.

Table 6. Distribution of theses by research design

\begin{tabular}{ccccccccc}
\hline Theme & Code & \multicolumn{2}{c}{ Master's thesis } & \multicolumn{2}{c}{ Doctoral thesis } & \multicolumn{2}{c}{ Total } \\
\hline \multirow{3}{*}{$\begin{array}{c}\text { Research } \\
\text { Method }\end{array}$} & Q & $\mathbf{\%}$ & $\mathbf{f}$ & $\mathbf{\%}$ & $\mathbf{f}$ & $\mathbf{\%}$ \\
\cline { 2 - 9 } & Quantitative & 29 & 23.02 & 3 & 15 & 32 & 21.92 \\
\cline { 2 - 9 } & Qualitative & 18 & 14.29 & 2 & 10 & 20 & 13.70 \\
\cline { 2 - 9 } & Mixed-Methods & 79 & 62.70 & 15 & 75 & 94 & 64.38 \\
\hline \multirow{2}{*}{ Total } & & $\mathbf{1 2 6}$ & $\mathbf{1 0 0}$ & $\mathbf{2 0}$ & $\mathbf{1 0 0}$ & $\mathbf{1 4 6}$ & $\mathbf{1 0 0}$ \\
\hline
\end{tabular}

As for Table 6, the research design of the theses displayed that the majority of researchers adopted mixed-methods approach as their preferred method of investigation $(64.38 \%, \mathrm{f}=94)$. Explanatory sequential design and convergent parallel design were among the most commonly adopted methods. Mixed-methods approach was found as the most popular research design across both categories of theses, and it was employed in as high as $75 \%(\mathrm{f}=15)$ of doctoral theses. According to the statistical results, quantitative research 
method was adopted in $23.02 \%$ ( $\mathrm{f}=29$ ) of the master's theses, while only $14.29 \%$ ( $\mathrm{f}=18)$ of the master's theses featured qualitative method. Only a quarter of the doctoral theses employed either quantitative $(\mathrm{f}=3)$ or qualitative method $(\mathrm{f}=2)$. Qualitative research across the theses often consisted of single or multiple case studies as well as experimental and phenomenological research, while correlational studies, quasi-experimental, or descriptive research were mainly utilized in master's and doctoral theses adopting a quantitative approach. These findings are in accordance with the latest research syntheses (e.g., Durak et al., 2018; Şişman et al., 2019), but not in other studies, in which quantitative research design was found to be the most commonly used methodology in both educational technology and ELT research (e.g., Göktaş et al., 2012; İnal et al., 2016; Küçük et al., 2013; Solak, 2014; Yağız et al., 2016). This finding is perhaps not surprising given the present synthesis covers the period of 2016 and 2020, and there is an upward trend in tendency to use mixed-methods design in the recent years as indicated in the fields of educational technology (e.g., Durak et al., 2017) and ELT (Şişman et al., 2019).

Table 7. Distribution of theses by data collection tools

\begin{tabular}{|c|c|c|c|c|c|c|c|}
\hline \multirow[t]{2}{*}{ Theme } & \multirow[t]{2}{*}{ Code } & \multicolumn{2}{|c|}{$\begin{array}{c}\text { Master's } \\
\text { thesis }\end{array}$} & \multicolumn{2}{|c|}{$\begin{array}{c}\text { Doctoral } \\
\text { thesis }\end{array}$} & \multicolumn{2}{|c|}{ Total } \\
\hline & & $\mathbf{f}$ & $\%$ & $\mathbf{f}$ & $\%$ & $\mathbf{f}$ & $\%$ \\
\hline \multirow{7}{*}{$\begin{array}{c}\text { Data } \\
\text { Collection } \\
\text { Tools }\end{array}$} & Survey/Questionnaire & 89 & 29.87 & 16 & 20.00 & 105 & 27.78 \\
\hline & Interview & 80 & 26.85 & 14 & 17.50 & 94 & 24.87 \\
\hline & Knowledge/Achievement Test & 63 & 21.14 & 16 & 20.00 & 79 & 20.90 \\
\hline & Reflection Paper/Journal & 23 & 7.72 & 9 & 11.25 & 32 & 8.47 \\
\hline & Observation/Field note & 15 & 5.03 & 9 & 11.25 & 24 & 6.35 \\
\hline & Participant Work & 15 & 5.03 & 9 & 11.25 & 24 & 6.35 \\
\hline & Others & 13 & 4.36 & 7 & 8.75 & 20 & 5.28 \\
\hline Total & & 298 & 100 & 80 & 100 & 378 & 100 \\
\hline
\end{tabular}

Table 7, which shows the distribution of master's and doctoral theses by data collection tools, illustrated that three tools were the most commonly employed means of collecting data in both types of theses: survey/questionnaire $(27.78 \%, f=105)$, interview $(24.87 \%, \mathrm{f}=94)$, knowledge/achievement tests $(20.90 \%, \mathrm{f}=79)$. Following these data collection tools, reflection papers or journals (e.g., teacher diary notes) and observation / field notes (e.g., screen capturing recordings) were commonly used as a means of gathering data for the research. The data were collected through participant work $(6.35 \%, \mathrm{f}=24)$ as well, which featured documents such as online peer feedback comments, participants' lesson plans, 
assignments, learner essays, blog posts, and discussion forum posts. These findings are in tune with the literature, in which survey/questionnaire, interviews, and achievement tests were commonly reported among the preferred data collection tools (e.g., Durak et al., 2018; Göktaş et al., 2012; Solak, 2014)

Table 8. Distribution of theses by data analysis methods

\begin{tabular}{ccccccccc}
\hline \multirow{2}{*}{ Theme } & Code & \multicolumn{2}{c}{$\begin{array}{c}\text { Master's } \\
\text { thesis }\end{array}$} & \multicolumn{2}{c}{$\begin{array}{c}\text { Doctoral } \\
\text { thesis }\end{array}$} & \multicolumn{2}{c}{ Total } \\
\hline \multirow{3}{*}{$\begin{array}{c}\text { Data Analysis } \\
\text { Methods }\end{array}$} & f & $\mathbf{\%}$ & $\mathbf{f}$ & $\mathbf{\%}$ & $\mathbf{f}$ & $\mathbf{\%}$ \\
\cline { 2 - 8 } & Descriptive analysis & 91 & 36.55 & 13 & 27.08 & 104 & 35.02 \\
\cline { 2 - 8 } & Inferential analysis & 58 & 23.29 & 17 & 35.42 & 75 & 25.25 \\
\cline { 2 - 8 } & Qualitative analysis & 100 & 40.16 & 18 & 37.50 & 118 & 39.73 \\
\hline Total & & $\mathbf{2 4 9}$ & $\mathbf{1 0 0}$ & $\mathbf{4 8}$ & $\mathbf{1 0 0}$ & $\mathbf{2 9 7}$ & $\mathbf{1 0 0}$ \\
\hline
\end{tabular}

As displayed in Table 8, the gathered data were analyzed by means of quantitative (i.e., descriptive analysis and inferential analysis) and qualitative analyses. Quantitative analysis was the most preferred data analysis method across both master's theses $(59.84 \%$, $\mathrm{f}=149)$ and doctoral theses $(62.5 \%, \mathrm{f}=30)$. While descriptive analysis was more commonly adopted than inferential analysis in master's research $(36.55, \mathrm{f}=91)$, inferential analysis was employed more in doctoral theses $(35.42, \mathrm{f}=17)$. The types of inferential analyses that were statistically run in all types of theses consisted of non-parametric tests (e.g., Wicoxon Signed ranks, Mann Whitney U, Kruskal Wallis, Kolmogorov-Smirnov, Shapiro-Wilk tests), t-tests (e.g., paired sample, independent sample), ANOVA/ANCOVA, and regression analysis. The collected data in the theses examined were qualitatively analyzed in a relatively high percentage for both master's research $(40.16 \%, \mathrm{f}=100)$ and doctoral theses $(37.50 \%, \mathrm{f}=18)$. The means of qualitative analysis across both types of theses often featured content and thematic analyses, which were followed by other methods such as constant comparative analysis. However, only a limited number of research $(\mathrm{f}=10)$ adopted digital qualitative analysis tools for the purpose of data analysis. MAXQDA $(f=6)$ was the most popular qualitative data analysis software, which was followed by NVivo ( $\mathrm{f}=2$ ) and Atlas.ti $(\mathrm{f}=2)$. Research syntheses in the literature generally support these findings (e.g., Göktaş et al., 2012) although some studies reported a balance between descriptive and inferential analyses unlike the present study (e.g., Durak et al., 2018). Considering the predominance of the quantitative research 
across the analyzed research, it is not surprising to see quantitative analysis methods being employed more than qualitative analysis.

Table 9. Distribution of theses by participant groups

\begin{tabular}{|c|c|c|c|c|c|c|c|}
\hline Theme & Code & & $\begin{array}{l}\text { ter's } \\
\text { sis }\end{array}$ & & $\begin{array}{l}\text { oral } \\
\text { sis }\end{array}$ & & tal \\
\hline \multirow{13}{*}{$\begin{array}{l}\text { Participant } \\
\text { Group }\end{array}$} & & $\mathbf{f}$ & $\%$ & $\mathbf{f}$ & $\%$ & $\mathbf{f}$ & $\%$ \\
\hline & Undergraduate students & 57 & 40.14 & 8 & 36.36 & 65 & 39.63 \\
\hline & Pre-service EFL Teachers & 14 & 9.86 & 9 & 40.90 & 23 & 14.02 \\
\hline & In-service EFL Teachers & 18 & 12.68 & 2 & 9.10 & 20 & 12.20 \\
\hline & Univ.-level EFL instructors & 16 & 11.28 & 1 & 4.55 & 17 & 10.36 \\
\hline & High school students (9-12) & 13 & 9.16 & 1 & 4.55 & 14 & 8.54 \\
\hline & Secondary students (5-8) & 8 & 5.63 & 0 & 0 & 8 & 4.88 \\
\hline & Others & 7 & 4.93 & 1 & 4.55 & 8 & 4.88 \\
\hline & Primary students (1-4) & 5 & 3.52 & 0 & 0 & 5 & 3.05 \\
\hline & Faculty members & 1 & 0.70 & 0 & 0 & 1 & 0.61 \\
\hline & Early childhood students & 1 & 0.70 & 0 & 0 & 1 & 0.61 \\
\hline & Parents & 1 & 0.70 & 0 & 0 & 1 & 0.61 \\
\hline & Documents & 1 & 0.70 & 0 & 0 & 1 & 0.61 \\
\hline Total & & 142 & 100 & 22 & 100 & 164 & 100 \\
\hline
\end{tabular}

Table 10. Distribution of theses by sample size

\begin{tabular}{cccccccc}
\hline Theme & Code & \multicolumn{2}{c}{ Master's thesis } & \multicolumn{2}{c}{ Doctoral thesis } & \multicolumn{2}{c}{ Total } \\
\hline & & $\mathbf{f}$ & $\mathbf{\%}$ & $\mathbf{f}$ & $\mathbf{\%}$ & $\mathbf{f}$ & $\mathbf{\%}$ \\
\cline { 2 - 9 } & $31-100$ & 67 & 53.17 & 5 & 25 & 72 & 49.33 \\
\cline { 2 - 8 } & $101-300$ & 26 & 20.63 & 5 & 25 & 31 & 21.23 \\
\cline { 2 - 8 } Sample & $11-30$ & 21 & 16.67 & 6 & 30 & 27 & 18.49 \\
\cline { 2 - 8 } number & $1-10$ & 10 & 7.94 & 1 & 5 & 11 & 7.53 \\
\cline { 2 - 8 } & $301-1000$ & 2 & 1.59 & 2 & 10 & 4 & 2.74 \\
\cline { 2 - 8 } & more than 1000 & 0 & 0 & 1 & 5 & 1 & 0.68 \\
\hline Total & & $\mathbf{1 2 6}$ & $\mathbf{1 0 0}$ & $\mathbf{2 0}$ & $\mathbf{1 0 0}$ & $\mathbf{1 4 6}$ & $\mathbf{1 0 0}$ \\
\hline
\end{tabular}

The research trends across the examined theses were analyzed by means of sample groups and sample size as well (Table 9, Table 10). Undergraduate students, commonly including preparatory class students (e.g., medicine, engineering), were frequently involved in a high number of master's thesis research $(40.14 \%, \mathrm{f}=57)$. Other participant groups included in-service EFL teachers, university-level EFL instructors, and secondary and high school students. Faculty members $(0.70 \%)$, early childhood students $(0.70 \%)$, parents $(0.70 \%)$, and documents $(0.70 \%)$, were the least chosen populations. University-level students (i.e., undergraduate students and pre-service EFL teachers) were included in more than threequarters of doctoral thesis research $(77.26 \%, \mathrm{f}=17)$. The remaining participant groups across 
doctoral theses were in-service EFL teachers $(\mathrm{f}=2)$, university-level EFL instructors $(\mathrm{f}=1)$, high school students $(f=1)$, and others $(f=1)$. The frequently preferred sample sizes were groups of $31-100(49.33 \%, \mathrm{f}=72), 101-300(21.23 \%, \mathrm{f}=31)$, and $11-30(18.49 \%, \mathrm{f}=27)$ in both master's and doctoral theses, which also provided insight regarding the preferred research designs. Findings regarding participant groups (i.e., undergraduate students) and sample sizes (i.e., 31-100 participants) concurred well with the findings from the literature, particularly in the field of ELT (e.g., Cesur et al., 2018; Solak, 2014; Yağ1z et al., 2016). The fact that young learners were included in the research in a limited way was also present in the previous research syntheses (e.g., Özmen et al., 2016). Therefore, it can be assumed that ELT research with an educational technology focus follows the similar trends of ELT studies with respect to sample groups and sizes.

\section{Conclusion and Suggestions}

The present study aimed to investigate English language teaching and learningrelated educational technology theses for the period between 2016 and 2020 through a descriptive content analysis methodology. The theses were examined to illustrate research trends across both master's and doctoral theses in the context of Turkey and to shed a light on the broad picture of the field as well as paving the way for the future research and the policymakers. The findings indicated that the research focus of theses was attitudinal studies and research examining digital literacies and $21^{\text {st }}$ century skills. It was found that four groups of technologies were strongly prevalent and these technologies were CALL resources in general, video-based materials, skill-based Web 2.0 tools, and learning management systems (LMS) and e-learning platforms. The findings further revealed that the majority of researchers employed mixed-methods approach, frequently employed survey, interview, and achievement tests as data collection tools, and often analyzed the data by means of quantitative analysis method. In the light of the present study's results, the following suggestions should be taken into consideration for future studies:

The educational technology research is growing quickly in the field of English language teaching and learning in the context of Turkey, which necessitates further research synthesis and analysis including periodicals in national and international indices. In addition, content analysis might focus on a specific aspect of educational technology (e.g., 
social media technologies, interactive web tools) or a language area/skill such as pronunciation, which is considered as one of the least studied areas in the EFL context (Arıkan \& Y1lmaz, 2020).

Based on the findings of the research synthesis regarding the limited number of qualitative methodology-oriented research, it is recommended that some future studies could adopt qualitative research techniques more in the examination of technology-enhanced English language teaching and learning practices. Besides, researchers should investigate the educational technology-related phenomena in ELT settings through longitudinal studies, which would further the knowledge in the scholarship. Given the dominance of quantitative data collection tools (i.e. questionnaires) in the field, it is also important that future studies rely on naturally occurring classroom data (İnal et al., 2016), which would enrich the results and provide a detailed inside perspective to the phenomena examined.

As the content analysis indicated a high percentage of undergraduate students' involvement in the studies, future research should target young learners as well. Considering the fact that children in Turkey are introduced to English as early as $2^{\text {nd }}$ grade in public schools, the number of research featuring young learners should increase and have more representation in ELT research in general as well (İnal et al., 2016; Solak, 2014). Furthermore, other participant groups such as administrators and parents could be valuable to illustrate multiple aspects of technology use for second language teaching and learning purposes, thus yielding a wide range of results.

Regarding the topics of the investigation, the following areas are recommended for further examination: the role of technology in testing and assessment, learners' digital collaborative practices, the affordances of telecollaboration, in-service teacher education and online professional development, massively multiplayer online games, social networking sites and apps developed for language learning purposes (e.g., Duolingo), technologymediated second language identity construction and development, intelligent technologies such as wearable devices and immersive technologies, and learners' digital translingual practices. Considering the developmental phase of digital technologies, ELT researchers exploring such technologies are suggested to follow technologies developments closely and 
design their research through a deeply-rooted theoretical and methodological lens following an interdisciplinary approach.

Acknowledgement

The data used in this study does not require the approval of Institutional Ethical Review Board.

\section{Authorship Contribution Statement}

Osman SOLMAZ: Conceptualization, design of the work, , literature search, data collection, data analysis, data interpretation, writing - review and editing.

\section{References}

Arıkan, A., \& Yılmaz, A. F. (2020). Pre-service english language teachers' problematic sounds. International e-Journal of Educational Studies (IEJES), 4 (7), 1-26.

Aydınlı, J., \& Ortaçtepe, D. (2018). Selected research in applied linguistics and English language teaching in Turkey: 2010-2016. Language Teaching, 51(2), 210-245.

Cesur, K., Muhammed, K. Ö. K., \& Aydın, Ç. (2018). Content analysis of abstracts on ELT research available in Turkish journalpark academic platform. ELT Research Journal, 7(2), 58-77.

Chen, Z., Chen, W., Jia, J., \& An, H. (2020). The effects of using mobile devices on language learning: a meta-analysis. Educational Technology Research and Development, 68(4), 17691789.

Dirlikli, M., Aydın, K., \& Akgün, L. (2016). Cooperative learning in Turkey: A content analysis of theses. Educational Sciences: Theory E Practice, 16(4), 1251-1273.

Durak, G., Çankaya, S., Yünkül, E., Urfa, M., Topraklıklığlu, K., Arda, Y., \& İnam, N. (2017). Trends in distance education: A content analysis of master's thesis. TOJET: The Turkish Online Journal of Educational Technology, 16(1), 203-218.

Durak, G., Çankaya, S., Yunkul, E., \& Misırlı, Z. A. (2018). A content analysis of dissertations in the field of educational technology: The case of Turkey. Turkish Online Journal of Distance Education, 19(2), 128-148.

Gökmen, Ö. F., Uysal, M., Yasar, H., Kirksekiz, A., Güvendi, G. M., \& Horzum, M. B. (2017). Methodological trends of the distance education theses published in Turkey from 2005 to 2014: A content analysis. Education and Science, 42(189), 1-25.

Göktaş, Y., Kucuk, S., Aydemir, M., Telli, E., Arpacik, O., Yildirim, G., \& Reisoglu, I. (2012). Educational technology research trends in Turkey: A content analysis of the 2000-2009 decade. Educational Sciences: Theory and Practice, 12(1), 191-199.

Güler, H., \& Taş, E. (2020). Thematic content analysis for pre-school science education research areas in Turkey. Journal of Computer and Education Research, 8(15), 323-343.

Inal, D., Özdemir, E., Kiray, G., \& Oral, Y. (2016). Review of doctoral research in English language teaching and learning in Turkey (2009-2013). Language Teaching, 49(3), 390410. 
Kessler, G. (2018). Technology and the future of language teaching. Foreign Language Annals, 51(1), 205-218.

Kirmız1, O. (2012). Research trends in MA ELT programs in Turkey. Procedia-Social and Behavioral Sciences, 46, 4687-4691.

Koçyiğit, M., \& Erdem, C. (2018). A content analysis of graduate research on English preparatory programs at universities. Journal of Human Sciences, 15(3), 1466-1480.

Küçük, S., Aydemir, M., Yildirim, G., Arpacik, O., \& Goktas, Y. (2013). Educational technology research trends in Turkey from 1990 to 2011. Computers $\mathcal{E}$ Education, 68, 4250.

Özmen, K. S., Cephe, P. T., \& Kinik, B. (2016). Trends in doctoral research on English language teaching in Turkey. Educational Sciences: Theory and Practice, 16(5), 1737-1759.

Parmaxi, A., \& Zaphiris, P. (2016). Web 2.0 in Computer-Assisted Language Learning: a research synthesis and implications for instructional design and educational practice. Interactive Learning Environments, 25(6), 704-716.

Shadiev, R., Hwang, W. Y., \& Huang, Y. M. (2017). Review of research on mobile language learning in authentic environments. Computer Assisted Language Learning, 30(3-4), 284303.

Solak, E. (2014). The Content analysis of the research papers on foreign language education in Turkey. International Journal of English and Education, 3(3), 167-178.

Strelan, P., Osborn, A., \& Palmer, E. (2020). The flipped classroom: A meta-analysis of effects on student performance across disciplines and education levels. Educational Research Review, 30100314.

Şimşek, M. R., \& Dündar, E. (2017). Investigating EFL coursebook research in Turkey: Trends in graduate theses of the 2001-2013 period. Educational Sciences: Theory E Practice, 17(3), 969-1014.

Şişman, E. P., Büyükkarc1, K., \& Özyurt, E. (2019). Research in ELT: Turkish Context. In Proceedings of the 3rd International Congress on Research in Education, 91-100.

Uzunboylu, H., \& Kocakoyun, S. (2016). A content analysis of master and doctorate thesis in the area of gamification. International Journal of Innovative Research In Education, 3(3), 143-154.

Yağız, O., Aydın, B., \& Akdemir, A. S. (2016). ELT research in Turkey: A content analysis of selected features of published articles. Journal of Language and Linguistic Studies, 12(2), 117-134.

Yıldırım, A., \& Şimşek, H. (2013). Sosyal bilimlerde nitel araştırma yöntemleri (Qualitative research methods in social sciences) (9th ed.). Ankara: Seçkin Yayınevi.

Yıldız, E. P., Cengel, M., \& Alkan, A. (2020). Current trends in education technologies research worldwide: Meta-analysis of studies between 2015-2020. World Journal on Educational Technology: Current Issues, 12(3), 192-206. 
Appendix 1. Theses included in the present study

\begin{tabular}{|c|c|c|c|}
\hline $\begin{array}{l}\text { The } \\
\text { sis }\end{array}$ & Title & Author* & Year \\
\hline MA & $\begin{array}{l}\text { English teachers' opinions about using songs to teach English to children (The sample of Diyarbakır } \\
\text { city) }\end{array}$ & ocuk & 16 \\
\hline MA & The effectiveness of augmented reality supported materials on vocabulary learning and retention & Doğan & 2016 \\
\hline MA & Learning to teach English through sitcoms: A case study of pre-service EFL teachers & Ökcü & 2016 \\
\hline MA & $\begin{array}{l}\text { The relationship between student attitudes towards English and teachers' technology use in EFL } \\
\text { classes }\end{array}$ & Selek & 16 \\
\hline MA & Examining the influence of flipped classroom on students learning English as a foreign language & Çalışkan & 2016 \\
\hline $\mathrm{PhD}$ & Motivating and engaging EFL learners in e-learning with game elements & Özkan & 2016 \\
\hline MA & $\begin{array}{l}\text { The perspectives of English as a Foreign Language (EFL) instructors on the use of mobile applications } \\
\text { as educational tools }\end{array}$ & Tutal & 2016 \\
\hline $\mathrm{PhD}$ & $\begin{array}{l}\text { The effect of audio and video modality on listening comprehension of reduced forms in sentential } \\
\text { level: The role of web-based learning }\end{array}$ & $\mathrm{Gi}$ & 2016 \\
\hline MA & EFL students' online peer feedback stances and preferences for revision & & 2016 \\
\hline MA & The role of using facebook in an EFL writing context and students' perce & & 2016 \\
\hline MA & $\begin{array}{l}\text { English language instructors' perceptions and use of interactive whiteboards in English as a foreign } \\
\text { language classrooms }\end{array}$ & Murat & 2016 \\
\hline MA & $\begin{array}{l}\text { The perceptions and challenges of young learners' EFL teachers towards interactive whiteboard use in } \\
\text { EFL classes }\end{array}$ & G & 2 \\
\hline MA & $\begin{array}{l}\text { Exploring the role of digital storytelling in vocabulary learning and retention: A case study at Harran } \\
\text { University }\end{array}$ & Öz & 2016 \\
\hline MA & $\begin{array}{l}\text { Teaching English for specific purposes through the use of information and communication } \\
\text { technologies and multimedia in Turkish Military Academy: A study on YouTube }\end{array}$ & y1 & 2016 \\
\hline MA & $\begin{array}{l}\text { The investigation of technological pedagogical and content knowledge level by Turkish teachers of } \\
\text { English }\end{array}$ & $\mathrm{D}$ & 2016 \\
\hline MA & An experimental study on the effects of wikis on EFL writing motivation & Çelik & 2016 \\
\hline $\mathrm{PhD}$ & $\begin{array}{l}\text { The effects of explicit film-based instruction on English as a foreign language teacher trainees' } \\
\text { interpretation of implied meanings }\end{array}$ & Çeti & 2016 \\
\hline MA & l language learning environment on speaking anxiety & Gü & 2016 \\
\hline MA & $\begin{array}{l}\text { on English as a Foreign language learners' } \\
\text { nt }\end{array}$ & $\mathrm{O}$ & 2 \\
\hline $\mathrm{PhD}$ & 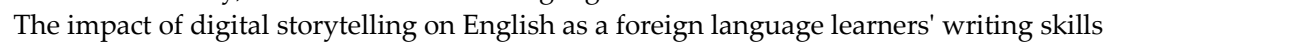 & & 2016 \\
\hline MA & & & 2016 \\
\hline MA & Eng & & 2017 \\
\hline MA & $\mathrm{E}$ & & 2017 \\
\hline MA & A study on students' attitude & $\mathrm{K}_{1}$ & 2017 \\
\hline MA & $\begin{array}{l}\text { Investigating the use of a mobile flashcard application Rememba on the vocabulary development and } \\
\text { motivation of Turkish EFL learners }\end{array}$ & Köse & 2017 \\
\hline MA & 1. & & 7 \\
\hline MA & $\begin{array}{l}\text { ollocations through data-driven learning activities in a } \\
\text { rs }\end{array}$ & $\begin{array}{l}\text { Akkoyunl } \\
\text { u }\end{array}$ & 2017 \\
\hline MA & Mobile- assisted vocabulary learning and its effect on vocabulary recall & Özer & 2017 \\
\hline MA & $\begin{array}{l}\text { In-service English teachers' use of information and communication technology for self-directed } \\
\text { professional development }\end{array}$ & Erdem & 2017 \\
\hline MA & Tweet circle: Effects of Twitter on EFL students' writing skill de & Eki & 2017 \\
\hline MA & $\begin{array}{l}\text { cturers' attitudes toward information and communication technologies } \\
\text { gy }\end{array}$ & Öztürk & 2017 \\
\hline MA & The effects of tablets & & 2017 \\
\hline MA & The effects of subtitled animation $\mathrm{r}$ & Ekinci & 2017 \\
\hline $\mathrm{PhD}$ & $\begin{array}{l}\text { Annotation and working memory in second language reading, incidental vocabulary learning, and } \\
\text { perceived cognitive load }\end{array}$ & Varol & 2017 \\
\hline MA & $\begin{array}{l}\text { A blended academic writing course for medical students: Diognosing EAP writing needs and syllabus } \\
\text { design }\end{array}$ & Kaplan & 2017 \\
\hline MA & Data-driven language learning: The use of concordance lines in vocabulary learning & & 2017 \\
\hline MA & & Kara & 2017 \\
\hline MA & rkish EFL 1 & Körlü & 2017 \\
\hline MA & The effects of using corpus-based materials in vocabulary instruction & Çilak & 2017 \\
\hline MA & A case study on teacher and student perceptions towards the online English exams & Çörekçioğl & 2017 \\
\hline
\end{tabular}


The perceptions of ELT students and teachers towards the use of IWBs at a vocational and technical high school

MA The contributions of using key-pal as a communication tool for English as a Foreign Language secondary school students

MA Foreign language teachers' interactions with their students on Facebook

MA A study on e-readiness of teachers in language classrooms

MA The effects of flipped classroom model on learner autonomy

MA A study of faculty members' and instructors' awareness, routines and use of Web 2.0 tools in foreign language teaching

MA Perceived roles and competencies of English language instructors in online learning environments

MA The analysis of learner autonomy and autonomous learning practices in massive open online language courses (MOOLCD)

MA Fostering students' L2 writing through interactive writing tools

The impact of video-based asynchronous computer-mediated communication of EFL learners' oral

MA language achievement and foreign language speaking anxiety

$\mathrm{PhD}$ 21st century learning: Integration of web 2.0 tools in Turkish adult language classrooms

MA The use of multiplayer online computer games in developing efl skills

MA

Impact of flipped classroom model on EFL learners' grammar achievement: Not only inversion, but also integration

MA

Effects of online differentiated reading in reading comprehension skills and learner autonomy of young learners

$\mathrm{PhD}$

Possible effects of employing video recording as a self-monitoring tool on pre-service EFL teachers' reflectivity and teaching knowledge

MA Exploring the effects of feedback types and wiki on EFL learners' writing performance

MA

Students' attitudes to the roles of teachers in task based learning method through web-assisted practices

MA Turkish EFL pre-service teachers' attitudes toward and reflections on digital game enhanced practice

MA

Comparison between Kahoot! and a traditional exercise in terms of vocabulary retention in EFL learners

$\mathrm{PhD}$

Tailoring blended instruction to underachieving language learners in order to enhance their productive language skills

MA

The effectiveness of using songs in teaching vocabulary to very young learners in a foreign language teaching classroom

MA The effects of critical thinking instruction through asynchronous learning tools on writing performance

$\mathrm{PhD}$ An investigation into English student teachers' behavioral intention to use information and communication technologies

A case study on the online English conversation classes through the use of Live Learning Program (LLP)

PhD The role of mobile-assisted language learning (MALL) in vocabulary knowledge, learner autonomy and motivation of prospective English language teachers

$\mathrm{PhD}$ Asynchronous distance learning and blended learning in terms of learner autonomy, motivation and academic success in teaching english

MA Flipped and blended grammar instruction for B1 level EFL classes at tertiary education

$\mathrm{PhD}$ Reading comprehension in paper and digital based English texts: A comparative study

MA The effectiveness of virtual reality tools on vocabulary learning and retention The effect of instrumental music and songs on vocabulary learning, reading comprehension and

MA motivation in English as a foreign language: A quasi-experimental study with Turkish high school students

PhD The impact of telecollaboration on learners' intercultural communicative competence and ideal L2 self

PhD The role of English language teachers' TPACK regarding high school students' acceptance of mobile learning tools

MA Visually impaired can watch films, too: Assessing the effects of audio description via film narrations

MA A study on the most commonly used Web 2.0 tools among Turkish high school teachers of English Exploring the effects of digital storytelling on young learners' motivation, vocabulary learning and retention in foreign language teaching

MA An analysis of preparatory school EFL instructors' perceptions on integrating internet-assisted technologies into classroom use

MA Let student learning drive the class: An investigation of the impact of flipped learning on EFL students' language skills, digital literacy and attitudes toward the learning environment MA The effect of metacognitive listening strategy instruction on EFL learners' listening comprehension and
awareness levels and the role of TED talks as a listening resource on students' perceptions

\begin{tabular}{|c|c|}
\hline Elmacı & 2017 \\
\hline Varışlı & 2017 \\
\hline Börekçi & 2017 \\
\hline Çalışkan & 2017 \\
\hline Çibik & 2017 \\
\hline Daşkın & 2017 \\
\hline Güneş & 2017 \\
\hline Misır & 2017 \\
\hline Yilmaz & 2017 \\
\hline Özdemir & 2018 \\
\hline Demir & 2018 \\
\hline Altınbaş & 2018 \\
\hline Bulut & 2018 \\
\hline Gülşen & 2018 \\
\hline Beceren & 2018 \\
\hline Altay & 2018 \\
\hline Koçak & 2018 \\
\hline イüftüoğlu & 2018 \\
\hline Ünal & 018 \\
\hline Aggun & 2018 \\
\hline Yilmaz & 2018 \\
\hline Aygün & 2018 \\
\hline $\mathrm{Baz}$ & 2018 \\
\hline Çelikbaş & 2018 \\
\hline Dağdeler & 2018 \\
\hline Güneş & 2018 \\
\hline Karakurt & 2018 \\
\hline Kazancı & 2018 \\
\hline Koçbuğ & 2018 \\
\hline Sevinç & 2018 \\
\hline Toscu & 2018 \\
\hline Yapar & 2018 \\
\hline Uul & 2019 \\
\hline Kayar & 2019 \\
\hline Bekar & 2019 \\
\hline Öztok & 2019 \\
\hline Tulay & 2019 \\
\hline Topa & 201 \\
\hline
\end{tabular}


MA The effects of online EFL assignments on student success: Mehmet Akif Ersoy University (MAKU)

Gölhisar Vocational School (GVS)

MA The impact of different media delivery modes on EFL learners' listening comprehension

Yalçın

MA

An investigation on the relationship between technology adopter categories and technological pedagogical content knowledge level of pre-service EFL teachers

Exploring factors that predict pre-service English teachers' intentions to use augmented reality using decomposed theory of planned behavior

MA

The impact of vocabulary learning strategies and computer assisted language learning on vocabulary development of Turkish high school students

MA Teachers' awareness and actual practices of 21st century learning and innovation skills

The views of ELT prep class students on internet-assisted language learning regarding learning management system

MA The effect technological tools on EFL learners' reading attitudes and motivations

Acar 2019

In-service EFL teacher's research experiences in an online professional learning community: A qualitative multiple case study

$\mathrm{PhD}$

The impact of flipped classroom approach on the reading and writing achievement, self-regulated learning, and classroom interaction of pre-service English teachers

$\mathrm{PhD}$ Developing digital literacies of pre-service EFL teachers through engagement with research An evaluation of the blended learning program of Ankara Yildirim Beyazit University preparatory school based on students' and instructors' perspectives

MA Pre-service EFL teachers' current practices and perceptions of mobile assisted language learning The impact of CLIL and techno-CLIL implementations on Turkish students' L2 vocabulary proficiency and reading development

Flipped vocabulary learning among Turkish learners of English as a Foreign Language: A sequential explanatory mixed method study

A case study in ninth grade students at a state school; differences between Kahoot! and traditional activities in terms of vocabulary retention

Individual and collaborative computerized concept mapping as a pre-writing strategy: Effects on EFL students' writing

MA An evaluation of a coursebook for 21st century's learning and innovation skills Developing listening comprehension skill through metacognitive strategy training in a tablet-assisted learning environment

MA The use of CALL to foster learner autonomy in EFL: A quasi-experimental study

MA A case study on innovative practices of English language teachers in flexible learning spaces

The effect of flipped learning-supported critical thinking instruction on the critical disposition and L2 writing skills

Using Web 3.0 technologies for teaching English to the primary level students: A study on augmented reality

The integration of ICT tools into listening skill classes to improve listening comprehension of EFL learners

Learning vocabulary with a computer-based vocabulary flashcard tool in a Turkish EFL High School context

The effect of using audiobooks as an extensive listening strategy on anxiety and development of listening and pronunciation skills of high school students learning English as a foreign language

The effects of automated writing evaluation on EFL students' writing achievement and motivation towards writing

PhD The effect of blog writing on Turkish EFL high schoolstudents' writing and vocabulary development

MA Learning English for academic purposes by using ubiquitous computing technology

MA The effects of a mobile phone application on Turkish EFL students' grammar learning Collaborative social learning: Using Edmodo as a social platform to teach efl writing for preparatory

MA school students

MA Automated writing evaluation use in an EFL context: From paragraph writing to essay writing

MA The role of cartoons in teaching grammar in EFL classes

MA Attitudes of ELT students and in-service teachers towards using mobile assisted language learning

MA Teaching foreign culture through songs

MA On the role of short films in enhancing reading comprehension skills: Critical discourse analysis of perceptions of efl students

MA The effects of TV series as curricular activities on speaking skills of English language learners Exploring the perceptions of language learners towards using a learning management system (LMS) at

MA an English preparatory school

MA The role of listening skills in the pronunciation of diphthongs through flipped classrooms

MA Comparing three different techniques for English vocabulary learning and retention

Şenen

Karacan

Kılıç 2019

Orak

Dilfiruz

Erdem

Yıldırım

2019

Aydemir

2019

Altıner

Bodur

Ünsal

Özkan

Emecen 


\begin{tabular}{|c|c|c|c|}
\hline MA & ne effects of Flipped Learning Model in teaching English grammar & Seçilmişoğlu & 2019 \\
\hline MA & he effect of flipped classroom on young learners' vocabulary learning in primary ELT classrooms & Şık & 2019 \\
\hline MA & ne effects of Quizlet on students' and EFL teachers' perceptions on vocabulary learning / teaching process & Toy & 2019 \\
\hline MA & $\begin{array}{l}\text { Investigating the impacts of mediated glosses on reading comprehension and vocabulary learning in } \\
\text { foreign language }\end{array}$ & Yuca & 2019 \\
\hline MA & $\begin{array}{l}\text { A corpus-based study on the English used in automotive engineering: Implications for teaching } \\
\text { English for specific purposes }\end{array}$ & Banlı & 2020 \\
\hline $\mathrm{PhD}$ & Corpora in foreign language teacher education: Introducing a corpus literacy course to ELT pre-service teachers & Şimşek & 2020 \\
\hline MA & The efficiency of mobile assisted language learning (MALL) in vocabulary learning & Atay & 2020 \\
\hline MA & $\begin{array}{l}\text { Exploring the predictive power of in-service EFL instructors' informal technology usage situations on } \\
\text { their TPACK levels }\end{array}$ & Dinçer & 2020 \\
\hline MA & $\begin{array}{l}\text { An action research: EFL students' perceptions and motivations towards flipped classroom and Web } 2.0 \\
\text { technology }\end{array}$ & Girgin & 2020 \\
\hline MA & $\begin{array}{l}\text { Exploring the predictive power of in-service efl instructors' informal technology usage situations on } \\
\text { their tpack levels }\end{array}$ & Yildiz & 2020 \\
\hline MA & The effect of Web 2.0 tools on Turkish EFL students' peer review types, attitude and writing performance & Guksu & 2020 \\
\hline MA & $\begin{array}{l}\text { Exploring in-service English Teachers' beliefs about using Web } 2.0 \text { tools and telecollaboration in } \\
\text { language teaching and learning process }\end{array}$ & Yücel & 2020 \\
\hline MA & An investigation into using Kahoot! for grammar practice from learners' and instructors' perspectives & Puğ & 2020 \\
\hline MA & Using Educational Informatics Network (EBA) as an educational learning platform in EFL courses in Turkey & Kurnaz & 2020 \\
\hline MA & University students' perceptions of mobile assisted language learning & Harbelioğlu & 2020 \\
\hline MA & The use of video materials in EFL learners' $r$ & Ekinci & 2020 \\
\hline MA & The effects of using Quizlet on vocabulary enhancement of tertiary level ESP learners & Arslan & 2020 \\
\hline MA & $\begin{array}{l}\text { An exploration of English as a Foreign Language (EFL) teachers' perceptions on 21st century learning } \\
\text { and innovation skills }\end{array}$ & Kaçar & 2020 \\
\hline MA & The effects of TED talks as extensive listening in Turkish EFL context & Çelik & 2020 \\
\hline MA & An investigation into EFL teachers' self-efficacy beliefs, frequency of use and attitudes $t$ & Yaprak & 2020 \\
\hline MA & The effects of blogging on enhancement of L2 learners' writing skills at preparatory class level & İş & 2020 \\
\hline MA & The role of English subtitles in English movies on EFL learners' content & Çağlar & 2020 \\
\hline MA & The use of EBA (Education Information Network) in teaching vocabulary and grammar to efl young learners & Pehlivan & 2020 \\
\hline MA & The effect of songs on pronunciation of young EFL le & Saldıraner & 2020 \\
\hline MA & $\begin{array}{l}\text { Effects of strategies-based instruction through Randall's Cyber Listening Lab and Quizizz on EFL } \\
\text { students' listening comprehension and strategy use }\end{array}$ & Şan & 2020 \\
\hline $\mathrm{PhD}$ & A case study on the implemantation of distance EFL education & Tur & 2020 \\
\hline MA & eaching in English as a foreign language class (EFL) & Yavuz & 2020 \\
\hline MA & A qualitative study on instructors' attitudes, readiness, and challenges toward flipped teaching in preparatory schools & Yılmaz & 2020 \\
\hline
\end{tabular}

* Surname of the author

Copyright (C JCER

JCER's Publication Ethics and Publication Malpractice Statement are based, in large part, on the guidelines and standards developed by the Committee on Publication Ethics (COPE). This article is available under Creative Commons CC-BY 4.0 license (https://creativecommons.org/licenses/by/4.0/) 